\title{
Planning Your Class to Take Advantage of Highly Effective Learning Techniques
}

James McGrath

Texas A\&M University School of Law, jmcgrath@law.tamu.edu

Follow this and additional works at: https://scholarship.law.tamu.edu/facscholar

Part of the Legal Education Commons

\section{Recommended Citation}

James McGrath, Planning Your Class to Take Advantage of Highly Effective Learning Techniques, $95 \mathrm{U}$. Det. Mercy L. Rev. 153 (2018).

Available at: https://scholarship.law.tamu.edu/facscholar/1278

This Article is brought to you for free and open access by Texas A\&M Law Scholarship. It has been accepted for inclusion in Faculty Scholarship by an authorized administrator of Texas A\&M Law Scholarship. For more information, please contact aretteen@law.tamu.edu. 


\title{
Planning Your Class to Take Advantage of Highly Effective Learning Techniques
}

\author{
JAMES MCGRATH*

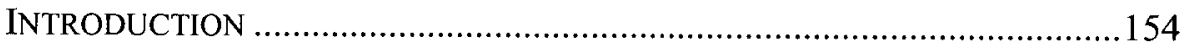 \\ I. ThE ChangIng University STUdENT POPULATION ....................156 \\ II. ABA STANDARDS ON ASSESSMENT ....................................... 160 \\ III. APPROACHES TO LEARNING ................................................ 163 \\ A. Intuitive Approaches to Learning that Work .........................163 \\ 1. Growth Mindset ........................................................ 164

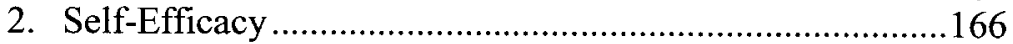

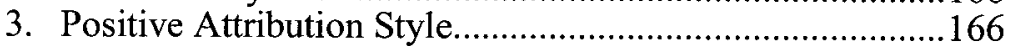

B. One Approach to Learning that is Intuitive, But May Not be Highly Effective-Learning Styles ......................................167

C. Rating Some of the most Effective, and Least Effective Learning Techniques ........................................................ 168

D. Learning Techniques with Low Utility Towards Long-Term Retention of Learning ..................................................... 168

IV. TECHNIQUES WITH HIGHER UTILITY TOWARDS LONG-TERM RETENTION OF LEARNING................................................... 170

A. Retrieval Practice or Practice Testing.................................170

B. Reflection ..................................................................... 172

C. Pretesting, Priming or Generation ...................................172

D. Distributed Practice, Spaced Practice, or Spacing..................173

E. Interleaved Practice or Interleaving.....................................176

F. Other Methods of Moderate Utility in Effective Long-Term Learning Retention .......................................................177

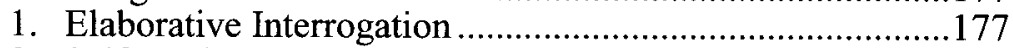

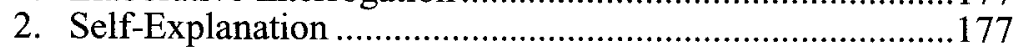

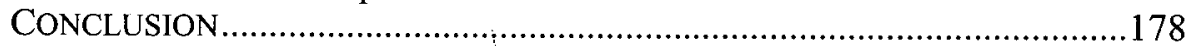

\footnotetext{
"Professor of Law and Associate Dean of Academic Support at Texas A\&M University School' of Law. I would like to thank our Dean, Andrew Morriss, for his unyielding support of our academic support program, and his dedication to keeping current with our literature. Also, I would like to thank my colleagues Camesha Little and DeShun Harris, both Assistant Directors of our program, for helping me develop and implement ambitious programming. Finally, I would like to applaud the students involved with coordinating the symposium and resulting volumes of articles, particularly the Symposium Director, Erin R. Cobane, whose tireless efforts made the symposium an incredible event.
} 


\section{INTRODUCTION}

What are the most highly effective learning techniques? Take a moment and consider what you think they are. Write them down if it is convenient. ${ }^{1}$ The symposium that is the subject of this law review volume examines the impact of formative assessment. In this article, I will connect formative assessment possibilities with ideas on how to take advantage of some of the proven highly effective learning techniques. The road there is a bit tortuous, but it is my hope that even the most well-informed teacher will find something that they can add to their quiver of techniques to help with her efforts of continually improve her teaching.

Academic Support faculty are often thought of as being warm, fuzzy, and nurturing types. ${ }^{2}$ One-on-one work with students, counseling on learning techniques and helping students through difficult times and concepts helps cement this reputation among our doctrinal faculty peers. For better or worse, this may not always be seen as positive, or even effective in training new lawyers. Intuitively, much of what we do makes sense, and not surprisingly, many of these intuitive concepts we champion are supported by empirical science. The power of embracing a growth mindset not only seems like a great idea, but is also supported by science. ${ }^{3}$ Some of these effective and intuitive concepts likely to be utilized in Academic Support Programs ("ASP") include promoting self-efficacy and adopting an optimistic self-attribution style, and are well supported by empirical evidence. ${ }^{4}$

When we look at the science of how people effectively learn-and by effectively I am referring to retaining that learning for the long term - the most successful methods are far from instinctive and some are downright counterintuitive. The law students that we admit are clearly bright people who have had success in higher education, and many are reticent to shed the techniques and strategies that have served them well in the past. Getting them to change their study methods by adopting unfamiliar and counter-intuitive techniques may be aided by modeling some of them in our classrooms. In this article, I will discuss some methods of planning classes to take advantage of the science of highly effective learning.

Any one professor's class, no matter how well designed and taught, will not ensure that our students will reach their goal of becoming successful lawyers. I argue that as legal educators, we can also better align our entire program of study to better train all of our students, while we embrace

1. Those of you who know what they are - and I am likely to be preaching to the choir with this article-are aware of the all too cute attempt to use one of them here.

2. There are obviously exceptions. My most popular nickname at my school is still "Bloodbath McGrath," despite many years of fostering adoption of these fuzzy methods.

3. See discussion infra Section III.A.1.

4. See discussion infra Sections III.A.2, III.A.3. 
the recently implemented American Bar Association ("ABA") requirements for assessment.

The revised ABA standards provide a terrific opportunity for schools to align their program goals with the instruction and assessment of our students. $^{5}$ The number of ABA accredited law schools grew steadily from 135 in 1965 to 201 by 2013 . $^{6}$ With this expansion came opportunities for many students, who would not otherwise have had an opportunity, to study law. A similar boom of students in undergraduate programs occurred many years earlier, causing education experts to examine how best to train students differently prepared to study at the undergraduate level. ${ }^{7}$ Although numbers are not destiny, many lower ranked law schools have student populations with historically low incoming indicators. ${ }^{8}$ I believe these law schools must do something more than intensify their current efforts. They need to make positive structural change to train their students to pass the bar exam and become ethical practicing lawyers. As the legal profession has always, and will continue to change, even higher ranked law schools interested in preparing "practice-ready" lawyers will necessarily have to align their programs to meet the changing pool of law students and the needs of the profession.

Part I begins with an examination of a constructivist's view of the changes in the preparation of university students generally, with some comparison to the changing pool of law students. Part II discusses the opportunity for substantial and positive change afforded by the fairly recently adopted ABA requirements for assessment. Part III explores those sometimes-fuzzy learning concepts that are not surprisingly effective. Part IV identifies some counterintuitive, yet highly effective techniques, and suggests ways in which we can incorporate some of these techniques into our classroom instruction to better serve our students and ultimately the profession.

5. See discussion infra Part II.

6. Jennifer Smith, Crop of New Law Schools Open Amid a Lawyer Glut, THE WALL STREET JouRNAL (last updated Jan. 31, 2013), https://www.wsj.com/articles/SB10001424127887323926104578276301888284108. Note that there were still law schools opening in 2011, the year that applications to law school began to fall precipitously. Id. See By Year Approved, Am. BAR Ass'N Section Of Legal EdUC. AND ADMISSIONS TO THE BAR (last visited Nov. 1, 2017), https://www.americanbar.org/groups/legal_education/resources/aba_approved_law_schools/ by_year_approved.html.

7. See discussion infra Part I.

8. Although lower LSAT and GPA scores of incoming students does not necessarily mean that these students do not appear "capable of satisfactorily completing" their course of study, the ABA appears to be watching this phenomenon closely in terms of continuing accreditation of law schools. Rebecca White Berch, Immediate Sanctions for Law Schools That Have Lowered Admissions Criteria? Not So Fast, 47 Syllabus (2016), http://www.americanbar.org/publications/syllabus_home/volume-47-2015-2016/syllabuswinter-2015-2016-47-2-/from-the-chair.html. 
My hope is that the reader will learn some techniques to use in planning and delivering their classes. I list these desired learning outcomes I have for you, the reader. After reading this article, the reader will: 1) understand the need for constant classroom and program evaluation, 2) be familiar with the proven highly effective learning techniques, and 3) learn new ideas for improving their students' learning retention, and perhaps generate new methods of their own.

\section{The ChangING UNIVERsity STUDENT POPULATION}

John Biggs and Catherine Tang described the changing population of college students, and the idea that students were less well prepared than in the past. ${ }^{9}$ They advocated for constructive alignment of university programs of study to better serve this new population of students. ${ }^{10}$ According to Biggs and Tang, constructive alignment is:

'Constructive' comes from the constructivist theory that learners use their own activity to construct their knowledge as interpreted through their own existing schemata. 'Alignment' is a principle in curriculum theory that assessment tasks should be aligned to what it is intended to be learned, as in criterion-referenced assessment. Constructive alignment extends in a practical way Shuell's statement that 'what the student does is actually more important in determining what is learned than what the teacher does' (1986: 429). The intended outcomes specify the activity that students should engage if they are to achieve the intended outcome as well as the content the activity refers to. The teacher's tasks are to set up a learning environment that encourages the student to perform those learning activities, and to assess student performances against the intended learning outcomes."

Constructive alignment grew out of the needs presented by the changing populations at universities. Worldwide, the rate of participation in higher education was around fifteen percent in the $1990 \mathrm{~s}$, whereas it is now over fifty percent in as many as fifty or more countries with some countries intending to increase that rate further. " In the United States ("U.S."), the

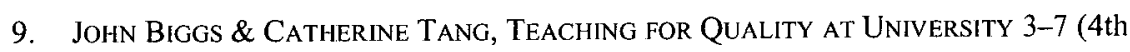
ed. 2011).

10. Id. at 104-109, 109 ("In a constructively aligned system, all componentsintended learning outcomes, teaching/learning activities, assessment tasks and their grading-support each other, so the learner is enveloped within a supportive learning system.").

11. Id. at 97 (citing Thomas J. Shuell, Cognitive Conceptions of Learning, 56 REv. EDUC. RES. 411, 429 (1986)).

12. BigGS \& TANG, supra note 9, at 4; Jack Grove, Global Participation Rates to Continue Rising, TIMES HIGHER EDUC. (Jan. 1, 2015), https://www.timeshighereducation.com/news/global-participation-rates-to-continue-risingsays-report/2017656.article; see PhILIP G. Altbach, Liz Reisberg \& LaURa E. Rumbley, Trends in Global Higher Education: Tracking an ACademic Revolution 1-21 (2009), http://www.cep.edu.rs/public/Altbach,_Reisberg,_Rumbley_Tracking_an_Academic_Revol 
increase may be even greater as about forty-five percent of high school graduates attended college in 1960 , with this percentage steadily increasing to over sixty-five percent in $1998 .^{13}$ Since 1998, the enrollment has fluctuated, but by 2015 the percentage was over sixty-nine percent. ${ }^{14}$ Looking at the sheer numbers of college-bound high school graduates in the fall of 2017 , about 20.4 million students were expected to matriculate, an increase of about 5.1 million since the fall of 2000 .

It has been estimated that slightly over one third of U.S. high school graduates are prepared for college-level coursework in math and reading. ${ }^{16}$ The preparation of these college bound students does not rise and fall uniformly. Although the top students in the U.S. are showing improvement in reading, for the lowest achieving students, reading performance is actually dropping. ${ }^{17}$

As the value of a high school diploma decreased, greater numbers of students began to matriculate in colleges, arriving with less consistent preparation for the rigors of higher education. Even more important may be these students' attitudes and motivation for learning. Biggs and Tang posit that previously, "in the good old days" (referring to the era when fewer high school graduates went on to college), there was a higher percentage of more intrinsically motivated students. Intrinsically motivated students are those with stronger foundations of relevant knowledge; students who engaged with the subject instinctively on a deeper level-by understanding, relating to and applying previous knowledge. ${ }^{18}$ When classrooms were

ution,_UNESCO_2009.pdf (report prepared for the United Nations Educational, Scientific and Cultural Organization 2009 World Conference on Higher Education).

13. Digest of Education Statistics, NAT'L CTR. FOR EDUC. STATISTICS (last visited Nov. 1, 2017), https://nces.ed.gov/programs/digest/d99/d99t187.asp (list of 1999 digest tables, table 187: college enrollment rates of high school graduates, by sex: 1960 to 1998).

14. Digest of Education Statistics, NAT'L CTR. FOR EDUC. STATISTICS (last visited Nov. 1, 2017), https://nces.ed.gov/programs/digest/d16/tables/dt16_302.30.asp?current=yes (list of 2016 digest tables, table 302.30: percentage of recent high school completers enrolled in two-year and four-year colleges, by income level: 1975 through 2015). Not surprisingly, the number of students in the U.S. attending college saw an increase in Americans earning degrees. In the U.S., in 2012, 33.5 percent of Americans ages twenty-five to twenty-nine had earned a bachelor's degree or higher. Catherine Campbell, Data Reveal a Rise in College Degrees Among Americans, N.Y. TIMEs (June 12, 2013), http://www.nytimes.com/2013/06/13/education/a-sharp-rise-in-americans-with-collegedegrees.html. This continues a trend of rising numbers of college graduates. In 1995, 24.7 percent and in 1975, it was 21.9 percent. $I d$. The number of two-year college degrees, master's degrees and doctorates has also risen recently. Id.

15. Fast Facts, NAT'L CTR. FOR EduC. STAtistics (last visited Nov. 1, 2017), https://nces.ed.gov/fastfacts/display.asp?id=372.

16. Lauren Camera, High School Seniors Aren't College Ready, U.S. NEwS AND WORLD REPORT (Apr. 27, 2016), https:/www.usnews.com/news/articles/2016-04-27/highschool-seniors-arent-college-ready-naep-data-show.

17. Id.

18. See BIGGS \& TANG, supra note 9, at 3-7. 
more heavily populated with such students, teachers did not have to do much more than lecture to these students who were motivated to learn on their own. As universities admitted larger numbers of students, the proportion of the self-motivated students declined as more students who were are not as intrinsically driven to acquire knowledge, with less of a foundation of relevant knowledge and likely to be more interested in simply passing and moving on, were admitted. ${ }^{19}$ Although both types of students populate the same classrooms and receive the same instruction, the latter acquires knowledge in a more shallow manner, making little or no connection to their prior learning.

As the intrinsically motivated students were capable of learning new material with little assistance from their instructors, college professors, who were also typically intrinsically motivated, tended to treat classes as if all their students were similarly minded, as indeed they likely were in the past. With the introduction of a larger pool of students with less preparation and not as intrinsically motivated, student performance overall suffered, creating a need for professors to employ more advanced teaching techniques to ensure that less prepared, differently motivated students could also succeed. ${ }^{20}$ Constructive alignment was one approach used to address these issues, and has been fairly successful. ${ }^{21}$

Some might argue as I do here, that the proliferation of U.S. law schools and later drop in the number of applicants, created a similar increase, not only of law students, but of the less intrinsically motivated type, the shallow learners. Similar to what occurred at undergraduate institutions, law professors formerly had the luxury of a high concentration of deep learners, those who learn in spite of the less than optimal type of instruction seen in traditional law classes. ${ }^{22}$ Professors at high-ranked law schools likely still see high percentages of these intrinsically motivated students. For the rest of us, similar to the way that the educators of our undergraduates have had to improve their teaching to meet their students on their level, we must do the same.

Adopting a conventional constructivist approach would be one option, but adopting the self-regulated learning theory would be a better fit in making this alignment for our current law school student population, ${ }^{23}$ and is

19. See id. at 5 .

20. See id.

21. Id. at $104-109$.

22. For example, little or no formative assessment, one summative assessment at the end of the semester-or year, etc.

23. As constructivism and other theories assume a basic level of preparation that may not be the case with many of our students. For a quick review of multiple learning theories, see Michael Hunter Schwartz, Sophie Sparrow \& Gerald Hess, Teaching law By Design: Engaging Students from the Syllabus to the Final Exam, 3-7 (2d ed. 2017), comparing various learning theories. Then read Chapter 5 , and see that these experts advocate teaching students to become self-regulated learners. Id. at 79-94. 
one theory espoused by long time proponents and law teaching experts $\mathrm{Mi}$ chael Hunter Schwartz, Sophie Sparrow and Gerald Hess in their popular text, "Teaching Law by Design: Engaging Students from the Syllabus to the Final Exam.",24

Self-regulated learning is best understood as a cycle involving three phases: a planning phase, in which the student decides how what when and where to study; an implementation phase, during which the student executes her plans; and a reflection phase, during which the student thinks back on her results and efforts, soberly evaluates her learning process, and plans how she will learn even better next time. ${ }^{25}$

In addition to this incredible guide for law professors, there is a wealth of great books, web pages, and articles ${ }^{26}$ dedicated to helping law students become self-regulated learners through this "active, constructive process whereby learners set goals for their learning and then attempt to monitor, regulate, and control their cognition.,"27

There is a text directed to helping law students become self-regulated learners, "Expert Learning for Law Students." 28 This book is a great alternative to the many "how to survive your first year of law school texts," which often corrupt the process of learning by advising students of shortcuts and easy ways to get by in law school. This year, our ASP is mailing a copy to each incoming student, and our peer-lead academic support sessions will be reinforcing its lessons. ${ }^{29}$

24. Id.

25. Id. at 8 .

26. For example, Michael Hunter SchWARTZ, EXPERT LeARning For LAW STUdENTS (2d ed. 2008), Louis Schulze, Using Cognitive Psychology to Improve Student Performance, Part Two: Metacognition and Self-Regulated Learning, THE FACULTY LOUNGE (Oct. 6, 2016), http://www.thefacultylounge.org/2016/10/using-cognitive-psychology-to-improvestudent-performance-part-two-metacognition-and-self-regulated-learning.html, as well as the other parts of his series on highly effective learning techniques, Louis N. Schulze Jr., Alternative Justifications for Academic Support II: How "Academic Support Across the Curriculum" Helps Meet the Goals of the Carnegie Report and Best Practices, 40 CAP. U.L. REV. 1 (2012), and Elizabeth M. Bloom, Teaching Law Students to Teach themselves: Using Lessons from Educational Psychology to Shape Self-Regulated Learners, 59 WAYNE L. REv. 311 (2013).

27. Ian Clark, Formative Assessment: Assessment Is for Self-regulated Learning, 24 Educ. Psychol. ReV. 205, 216 (2012) (quoting Paul R. Pintrich \& Akane Zusho, The Development of Academic Self-Regulation: The Role of Cognitive and Motivational Factors, in DEVElopMent of ACHIEVEMENT Motivation 250 (Allan Wigfield \& Jacquelynne S. Eccles eds., 2002)).

28. SCHWARTZ, supra note 26 , at 3-5.

29. Thanks again to our Dean Andrew Morriss, and our Assistant Dean of Admissions, Terrence Cook, for their support of this effort. 


\section{ABA STANDARDS ON ASSESSMENT}

The fairly recently adopted ABA rules ${ }^{30}$ on assessment provide an excellent opportunity to create meaningful change not only in the way that we assess our students in our classrooms, but for clarifying what skills and knowledge we expect each graduate to possess. To successfully do all of this, we must also challenge ourselves to become better teachers.

Many of us in the legal academy knew little of program assessment before the adoption of these standards. ${ }^{31}$ Unfortunately, formative assessment in the classroom was also too rare. Before the announcement that the ABA was implementing new rules requiring program assessment, the concept may have been daunting and probably unwelcome. ${ }^{32}$ Now part of the ABA Standards and Rules of Procedure or Approval of Law Schools, ${ }^{33}$ Standards $301,302,314$ and $315^{34}$ also provide an excellent impetus for modernizing our programs and classes. Attending one of the many seminars held on implementing the ABA standards on assessment, I heard a lot of grumbling about this new "inconvenience." Although the process is indeed a lot of work, the function of assessment is to help us guide our students in achieving the success that they, and we, desire. The word "assess" comes from the Latin word "assidere," which means "to sit beside." Thinking of assessment from this perspective, of having a conversation with the student to help her learn from her mistakes and confirm what she learned correctly, it should then be seen as a very powerful tool in educating our future lawyers. Faculty may not embrace these new responsibilities, and certainly most students do not view typical assessments as a posi-

30. 2015 Guidance Memo on Learning Outcomes, Managing Director's Guidance Memo Standards 301, 302, 314 and 315, AM. BAR ASs'N SECTION OF LEGAL EdUC. AND ADMISSIONS TO THE BAR (June https://www.americanbar.org/content/dam/aba/administrative/legal_education_and_admissi ons_to_the_bar/governancedocuments/2015_learning_outcomes_guidance.authcheckdam.p df.

31. Many schools likely dealt with program assessment previously for regional accreditation purposes.

32. Clearly, there were many law professors who previously had adopted learning outcomes/objectives in their classrooms, and there have been many leaders in modernizing legal education, such as the work of Michael Hunter Schwartz, Sophie Sparrow and Gerry Hess (our apologies to many others not mentioned). The focus on faculty scholarship is often seen as far more important than the study and implementation of effective teaching and learning.

33. ABA Standards and Rules of Procedure for Approval of Law Schools 2016-2017, Am. Bar Ass'n Section of Legal Educ. And Admissions to the Bar (Aug. 2016) at 1516 , 23-24, https://www.americanbar.org/content/dam/aba/publications/misc/legal_education/Standards/ 2016_2017_aba_standards_and_rules_of_procedure.authcheckdam.pdf.

34. 2015 Guidance Memo on Learning Outcomes, supra note 30.

35. Evangeline Harris Stefanakis, Multiple Intelligences and Portfolios: A WINDOW INTO THE LEARNERS MIND 9 (2002). 
tive aspect of law school. With summative assessment alone as their experience, it usually is not.

ABA Standard 314 requires the use of both formative and summative assessment, ${ }^{36}$ and is the standard that relates to assessment in the classroom. Standard 314-Assessment of Student Learning-requires "[a] law school shall utilize both formative and summative assessment methods in its curriculum to measure and improve student learning and provide meaningful feedback to students." 37 The ABA also clarifies the difference between formative and summative assessment:

Formative assessment methods are measurements at different points during a particular course or at different points over the span of a student's education that provide meaningful feedback to improve student learning. Summative assessment methods are measurements at the culmination of a particular course or at the culmination of any part of a student's legal education that measure the degree of student learning. ${ }^{38}$

Formative assessment in the classroom is the main focus of this article, but it clearly has value in the overall program assessment as well. The ABA falls short of requiring formative assessment in all classes, directing that "[a] law school need not apply multiple assessment methods in any particular course." 39 Unfortunately, this seems to permit continuing the pervasive practice of using one examination at the end of the semester as the only assessment in that course-a summative assessment. This method does little to help a student evaluate his own performance during a class and make corrections to his misunderstandings of the material. It is clear that formative assessment aids students in their studies, and as I will show, is an incredible method of learning.

Standards 301, 302 and 315 are concerned with the assessment of a law school's program of study. Standard 301 requires a law school to prepare its graduates for admission to the bar and for their "effective, ethical and responsible participation as members of the legal profession." 40 Standard 302 lists the minimum competencies that a law school shall adopt as their learning outcomes, ${ }^{41}$ while Standard 315 embraces an important facet

36. As if law schools had not been employing summative assessment.

37. ABA Standards and Rules of Procedure, supra note 33, at 23.

38. 2015 Guidance Memo on Learning Outcomes, supra note 30, at 2; ABA Standards and Rules of Procedure, supra note 33, at 23.

39. 2015 Guidance Memo on Learning Outcomes, supra note 30, at 2; ABA Standards and Rules of Procedure, supra note 33, at 23.

40. 2015 Guidance Memo on Learning Outcomes, supra note 30, at 1; ABA Standards and Rules of Procedure, supra note 33, at 15.

41. Standard 302-Learning Outcomes-provides:

(a) Knowledge and understanding of substantive and procedural law; (b) Legal analysis and reasoning, legal research, problem-solving, and written and oral communication in the legal context; (c) Exercise of proper professional and ethical responsibilities to clients and the legal system; and (d) Other professional 
of program assessment, the use of the results of program assessment to ensure student attainment of those competencies and to improve the program. $^{42}$

Law schools that are part of a larger university likely have access to the experience and programs developed previously by virtually every other discipline. Law is late to the assessment table, so can benefit from the work done by the many experts in this field. The process of program assessment can be charted as below, and provides an exhilarating or marrow sucking realization depending on your mindset - it never ends. We can continually tweak each component of assessment for continual improvement of our programs, or for our individual classes.

In a very basic overview, typically the first step is developing the program mission and the desired outcome for graduates of the program-or for your class. ${ }^{43}$ The next step of the assessment plan is to design a measure to determine whether the participants met your goals. Then the plan must be implemented, and information is gathered. The next step is to interpret the data you have been collecting to determine if you are meeting your goals. Finally, the most important step is to look at your results and modify your program - in my mind, whether or not you are meeting your goals. If you have met your goals, perhaps you have set the bar too low, as we can always improve. If you have not met your goals, you can modify the program to better prepare your students to meet your goals. Then repeat the whole process. Ad infinitum. As in the chart below, assessment is a continual process.

skills needed for competent and ethical participation as a member of the legal profession.

2015 Guidance Memo on Learning Outcomes, supra note 30, at 1; ABA Standards and Rules of Procedure, supra note 33, at 15 . This is the minimum required, and is often thought of as a good starting point for schools that are first implementing any program outcomes.

42. 2015 Guidance Memo on Learning Outcomes, supra note 30, at 2; ABA Standards and Rules of Procedure, supra note 33, at 23.

43. The process of assessment is beyond the scope of this article and I do not want to assume that the reader is not already an expert. I would recommend two texts for those interested in learning more about assessment. From the view of higher education generally, Trudy W. Banta \& Catherine A. Palomba, Assessment Essentials: Planning, Implementing, and Improving Assessment in Higher Education (2d ed. 2014). For law schools in specific, an incredible "how to" approach to program assessment is LORI E. SHAW \& Victoria L. VanZandt, STUdent Learning Outcomes and Law School AsSESSMENT: A Practical Guide to Measuring Institutional Effectiveness (2015). 


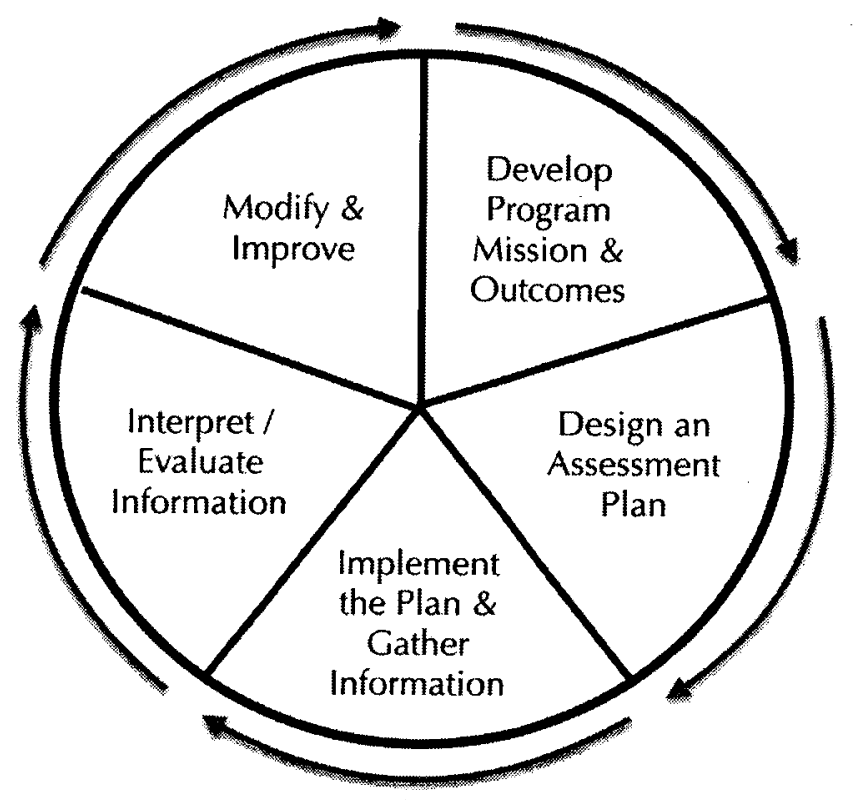

It is not only an assessment of our students' performance-but also of our performance as educators and curriculum designers.

\section{APPROACHES TO LEARNING}

The recent $\mathrm{ABA}$ standards are in part an effort to measure what students have learned, shifting the focus away from what we were teaching. ${ }^{44}$ To be effective teachers, it is important to examine the ways in which people actually learn effectively. In this article, effective learning is learning for the long term, as opposed to learning material to pass a test with little regard for long-term retention of the material. Clearly, law students need to retain their learning for the long term. First, it is impossible to successfully cram for the bar exam-there is just too much material to study and skills to acquire. Another benefit to better retention of learning would be a practicing lawyer having a sound foundational knowledge of the basic principles of law, which will aid her in issue spotting the legal concerns in her clients' stories of their problems.

\section{A. Intuitive Approaches to Learning that Work}

Many intuitive approaches to aiding students in learning material more effectively-not surprisingly-actually work. Below are a few of these concepts. This listing is not meant to be exhaustive, just some examples of what works and

44. 2015 Guidance Memo on Learning Outcomes, supra note 30, at 2; ABA Standards and Rules of Procedure, supra note 33, at 23. 
also perhaps "feels right." These approaches also work well in conjunction with the highly effective learning techniques.

\section{Growth Mindset}

Dr. Carol Dweck coined the terms "growth mindset" and "fixed mindset" to describe the beliefs that people have about their own learning and intelligence. ${ }^{45}$ A person with a growth mindset believes that with work, they can actually get smarter. ${ }^{46}$ Dweck's studies have shown that with this belief, these people actually do perform better than their peers with a fixed mindset: "students' mindsets-how they perceive their abilities--played a key role in their motivation and achieve- ment, and we found that if we changed students' mindsets, we could boost their achievement." 47

Dweck notes that no one has a "pure" growth mindset and that everyone is a "mixture of fixed and growth mindsets, and that mixture continually evolves with experience." 48 Neuroscience supports the ability of the brain to make and strengthen connections, in response to using good learning strategies (and with good nutrition and sleep habits as well). ${ }^{49}$

People with a more fixed mindset have some interesting characteristics. Fixed mindset students tend to value looking smart over achievement. ${ }^{50}$ They may avoid opportunities to learn that may put them at risk of publicly performing poorly, and are not likely to admit any deficiencies. ${ }^{51}$ They may have been praised often for their intelligence such that they may be afraid to be seen as someone who makes mistakes. ${ }^{52}$ Generally, these students do not like working hard, believing that they are born with a certain amount of intelligence, and the proper amount of learning should come easily. ${ }^{53}$ They also do not handle failure very well and can become easily discouraged. ${ }^{54}$ Students with a growth mindset generally view challenging work as opportunities for growth, and do not see mistakes as something negative, but part of the learning process. ${ }^{55}$

45. Carol S. DWeck, Mindset: The New Psychology of Success 6-7 (2006).

46. Id.

47. Carol Dweck, Carol Dweck Revisits the 'Growth Mindset,' Educ. WeEK (Sept. 22, 2015), http://www.edweek.org/ew/articles/2015/09/23/carol-dweck-revisits-the-growthmindset.html.

48. Carol Dweck, What Having a "Growth Mindset" Actually Means, HaRVARD Bus. REVIEW (Jan. 1, 2016), https://hbr.org/2016/01/what-having-a-growth-mindset-actuallymeans.

49. Decades of Scientific Research that Started a Growth Mindset Revolution, MINDSET WORKS (last visited Nov. 1, 2017), https://www.mindsetworks.com/science.

50. What Having a "Growth Mindset" Actually Means, supra note 48.

51. Id.

52. Lisa Trei, New Study Yields Instructive Results on How Mindset Affects Learning, STANFORD REPORT (Feb. 7, 2007), http://news.stanford.edu/news/2007/february $7 /$ dweck020707.html.

53. What Having a "Growth Mindset" Actually Means, supra note 48.

54. Id.

55. Id. 
Supporting adoption of a growth mindset may be particularly helpful for law students who have been told implicitly and explicitly their relative level of intelligence and abilities. Students are ranked prior to law school with their LSAT and GPA, then are usually sorted again by class rank in school where there is usually a mandatory curve of their performance. Students with a rigid fixed mindset are likely to see extra effort as futile or a waste of time. ${ }^{56}$ Those with a growth mindset are more likely to put in extra work when their efforts do not yield their desired level of success. The way we teach our classes and interact with them also affects a student's mindset. Telling students that they are highly intelligent can lead to students adopting a fixed mindset, whereas stressing that hard work leads to higher success helps students to adopt a growth mindset.

It is important to note that it is not having a growth mindset, but employing that growth mindset that leads to greater achievement. ${ }^{57}$ The benefits from a growth mindset are not only about hard work, but also about using different strategies when the usual methods do not work. ${ }^{58}$ The growth mindset has been widely adopted and touted, but Dweck is concerned about some misunderstandings and misuses of it. Dweck is concerned that her work will be used to categorize and stigmatize students by labeling a student as having a fixed mindset-_."he is a poor performer because he has such a fixed mindset." $" 59$ She is also worried that people will misuse her work to perpetuate the failed "self-esteem movement." "60 Her concern is that students will be praised for working hard, even if that hard work is not producing any results. ${ }^{61}$ Meaningful learning needs to challenge students, and it is our role as teachers to make the challenges exciting, or at least meaningful. Dweck notes that many teachers claim to imbue their students with a growth mindset, but their classrooms do not reflect it. ${ }^{62}$ The classroom should reflect challenge and support innovation by using multiple methods of solving these challenges. ${ }^{63}$

Although I am greatly concerned with helping our students to retain information, that is just one of our responsibilities as teachers. Ultimately, we would like our students to understand the material they learn. And that is hard work and often takes time. Dweck notes:

Teachers should also emphasize that fast learning is not always the deepest and best learning and that students who take longer sometimes understand things at a deeper level. Students can learn about many historical figures who were not regarded as

56. Lisa S. Blackwell, Kali H. Trzesniewski \& Carol Sorich Dweck, Implicit Theories of Intelligence Predict Achievement Across and Adolescent Transition: A Longitudinal Study and an Intervention, 78 CHILD DEv. 246, 247 (2007).

57. What Having a "Growth Mindset" Actually Means, supra note 48.

58. Carol Dweck Revisits the 'Growth Mindset,' supra note 47.

59. Id.

60. Id. Her work was originally developed to counter that movement, which in simple terms holds that "if you want to make students feel good, even if they're not learning, just praise their effort!" Id.

61. Id.

62. Id.

63. Id. 
"fast" learners in childhood. Albert Einstein swore that he was slow to learn and that's why he pondered the same questions year after year-with, as we know, excellent results. ${ }^{64}$

\section{Self-Efficacy}

Self-efficacy is the belief in your own ability to complete tasks and achieve goals. ${ }^{65}$ Put simply, if you believe you can do something-you will be more likely to be able to do it. Studies have shown students with high self-efficacy perform better academically than those with low self-efficacy. ${ }^{66}$ High self-efficacy has also been related to better health outcomes. ${ }^{67}$ This effect is not surprising, as a person who believes they can perform a task will more likely marshal the will and expend the effort required to make that happen. ${ }^{68}$ Although posited as a theory, the effect has been empirically supported as well. ${ }^{69}$ This concept is fairly simple, and people may understand it easily, but not actually embrace it. I like to remind them of the corollary, "if you do not believe you can do something, you are probably right."

\section{Positive Attribution Style}

As teachers, we can also reinforce a positive or optimistic attribution style in our students. Attribution style describes how a person explains the cause of various outcomes of their behavior. A person with an optimistic attribution style might explain not doing well on a test by saying, "I thought I prepared, but I see that I didn't fully understand (some concept), I will do better next time by working through problems involving (that concept) so that I truly understand it," where someone with a pessimistic attribution style might blame poor results on the test maker, or some other external factor. In general, the optimistic person sees results

64. Carol S. Dweck, Even Geniuses Work Hard, 68 Giving Students MEANINGFuL WORK $16,17 \quad(2010), \quad$ http://www.ascd.org/publications/educationalleadership/sept10/vol68/num01/Even-Geniuses-Work-Hard.aspx.

65. Albert Bandura, Self-Efficacy: Toward a Unifying Theory of Behavioral Change, 84 PSyCHOL. REV. 191, 194 (1977).

66. Sharon Andrew and Wilma Vialle, Nursing Students' Self-Efficacy, Self-Regulated Learning and Academic Performance in Science, AuSTL. ASS'N FOR RESEARCH IN EdUC. (1998) at 8, https://www.aare.edu.au/data/publications/1998/and98319.pdf. It should be noted that in the context of learning a foreign language, low self-efficacy was actually more helpful, as students who believed they were "good at languages," were likely to study less rigorously than those with a low self-efficacy towards learning languages. Christine Galbreath Jernigan, What Do Students Expect to Learn? The Role of Learner Expectancies, Beliefs and Attributions for Success and Failure in Student Motivation, 7 CuRRENT ISSUES EDUC. (ONLINE) 1, 1 (2004), https://cie.asu.edu/ojs/index.php/cieatasu/article/view/824/250.

67. Benicio Gutiérrez-Doña, Sonia Lippke, Britta Renner, Sunkyo Kwon \& Ralf Schwarzer, Self-Efficacy and Planning Predict Dietary Behaviors in Costa Rican and South Korean Women: Two Moderated Mediation Analyses, 1 APPLIED PSYCHOL. 91, 101 (2009).

68. Bandura, supra note 65 , at 194.

69. Muhammed Yusuf, The Impact of Self-Efficacy, Achievement Motivation, and SelfRegulated Learning Strategies on Students' Academic Achievement, 15 ProcedIA SOC. AND BEHAV. SCI. 2623, 2625 (2011). 
of their behavior as somewhat within their control, and the pessimistic person tends to favor external explanations for results. Negative attribution tendencies are related to lower grades, ${ }^{70}$ and a lower likelihood of becoming a self-regulated learner. ${ }^{71}$ Of special concern for law students, there is also a high correlation between a person's negative attribution style and depression. ${ }^{72}$

\section{B. One Approach to Learning that is Intuitive, But May Not be Highly Effective-Learning Styles}

All intuitively appealing concepts are not effective. Although many educators are heavily invested in using learning styles as a way to promote student learning, there is little evidence that discovering a student's preferred learning style, and making use of that knowledge, leads to long term retention of material. ${ }^{73}$ Learning styles advocates lists of the learning styles vary, but some common categories include: verbal, visual, musical, kinesthetic, solitary, social, logical, or a combination of these. There has been much written on learning styles, but there is no empirical support that adopting a learning styles approach to learning aids in long term retention of material or skills. ${ }^{74}$

There is however, literature that shows that students learn better with an eclectic approach to learning. ${ }^{75}$ In other words, an auditory learner will learn better if they mix up their learning with multiple learning styles. For me, this begs the question as to why we would concentrate on identifying a student's preferred style, when it has been shown that people learn better using a variety of these methods, and of course if we teach using a variety of methods as well.

There may be other reasons for and methods of utilizing a person's preferred learning style, but my focus here is in putting our efforts behind methods that are proven to help students retain their learning. From adopting a growth mindset through many of the following techniques, it is clear that effective learning is hard work, so efforts to make learning easier are likely to make learning less effective. ${ }^{76}$ Learning needs to challenge students. Determining and advocating for

70. Christopher Peterson, Explanatory Style on the Classroom and on the Playing Field, in AtTRIBution Theory: Applications to ACHIEVEMENT, MEnTAL Health, and INTERPERSONAL CONFLICT 53, 53 (Sandra Graham \& Valerie S. Folkes eds., 1990).

71. Petri Nokelainen, Kirsi Tirri, \& Hanna-Leena Merenti-Välimäki, Investigating the Influence of Attribution Styles on the Development of Mathematical Talent, 51 GIFTED CHILD Q. 64, 67 (2007).

72. Helen Cheng \& Adrian Furnham, Attribution Style and Personality as Predictors of Happiness and Mental Health, 3 J. HAPPINESS STud. 307, 308-10 (2001) (citations omitted).

73. Peter C. Brown, Henry L. Roediger III \& Mark A. McDaniel, Make It Stick: THE SCIENCE OF SuCCESSFUl LEARning 4 (2014).

74. Id.

75. E.g., Qaiser Suleman \& Ishtiaq Hussain, Effects of Eclectic Learning Approach on Students' Academic Achievement and Retention in English at Elementary Level, $7 \mathrm{~J}$. EDUC. \& PRAC. 32, 35 (2016).

76. If I hear one more person, when speaking of law school, say, "don't work harder, work smarter," I will explode. Working harder is working smarter. 
the use of a student's preferred learning style may be counter-productive, as that may likely be the style most comfortable for her, and therefore less work and make the learning less challenging.

\section{Rating Some of the most Effective, and Least Effective Learning Techniques}

A meta-analysis of ten learning of the most popular learning techniques was published in 2013, reviewing scores of prior studies to determine what learning techniques were effective for long term retention of learning. ${ }^{77}$ It might surprise most people that the most common methods students use for studying are not very effective for retaining material in the long term. Most of the methods that were supported by empirical evidence as having high utility in promoting long term retention of material are surprising to anyone who is not versed in this literature. I will review quickly the least effective, and some of the more effective methods that I believe we can make particular use to our students' advantage in law school, with some suggestions for implementing them.

\section{Learning Techniques with Low Utility Towards Long-Term Retention of Learning}

Some of the most popular learning techniques among our students include rereading, highlighting ${ }^{78}$ and cramming. All of these have low effectiveness in promoting long term learning. ${ }^{79}$ In attempting to persuade students to change the way they study, it is important to note that these methods have served most of our students well in their previous studies, as most law students did well in their undergraduate education. It is not that these methods do not work for passing courses, they just do not lead to long term retention of learning. ${ }^{80}$ Using these popular

77. John Dunlosky, Katherine A. Rawson, Elizabeth J. Marsh, Mitchell J. Nathan \& Daniel T. Willingham, Improving Students' Learning with Effective Learning Techniques: Promising Directions from Cognitive and Educational Psychology, 14 PSYCHOL. SCI. PUB. INT. 4 (2013). The authors also published a shorter, less dense version. John Dunlosky, Katherine A. Rawson, Elizabeth J. Marsh, Mitchell J. Nathan \& Daniel T. Willingham, What Works, What Doesn't, 24 SCI. AM. MIND 46 (2013).

78. Highlighting can have better effectiveness in certain circumstances, using fairly particular techniques. Improving Students' Learning with Effective Learning Techniques, supra note 77, at 18-20. Because law students tend to believe they are the exceptional person that is the exception to the rule, I recommend telling student that it generally has low effectiveness at helping them retain knowledge and point them to more effective techniques.

79. BROWN ET AL, supra note 73, at 3; Improving Students' Learning with Effective Learning Techniques, supra note 77 , at 21 . Another technique of low effectiveness is keyword mnemonics, which has better application to tasks such as foreign language vocabulary acquisition. Id. at 21-24. As law students are unlikely to use this technique, I relegate it to this footnote.

80. One other learning technique that has low utility is imagery use for text learning. It is not very popular among students, but I include it here as I have seen it pop up in some academic support materials. Although this technique shows promise under certain circumstances, it was rated as having low effectiveness for long term retention of learning. $I m$ proving Students' Learning with' Effective Learning Techniques, supra note 77, at 24-26. 
and comfortable methods, students have been high academic achievers, and are skeptical about changing what has worked for them in the past. I am loathing to report this, but students may actually perform slightly better using these low effectiveness techniques in the short term, but unfortunately, they will forget most of this learning fairly quickly as compared to study using the superior techniques. ${ }^{81}$

Rereading as a method of study works in the short term, and is one of the most popular study methods. ${ }^{82}$ Unfortunately, it gives students the illusion that they have learned the previously read material, an effect known as the "illusion of knowledge." 83 For example, when attempting to learn material by rereading, when reading a particular passage after the first time, you might think you remember the passage and say to yourself, "I remember this information." What may have happened is that you may remember having read it. If instead you had been asked about the content of the material, prior to your rereading, you likely would not have been able to recall it. This effect is known as the illusion of knowledge; you have fooled yourself into believing you learned the material when you actually just remember having read it. ${ }^{84}$ This is one of the reasons students prefer this method; it gives them false confidence that they are learning. Most people are not very capable at self-assessment, and rereading is part of the reason.

Highlighting, or underlining is a method of learning in which a student highlights the material that they find most important. This method has shown low utility in long term retention of learning. ${ }^{85}$ Problems with this technique include students not knowing what the important concepts are in their reading. Highlighting can also be used to identify concepts that they do not understand, with a plan to review it at some later time. In this method, the material is then read with little or no context to help the student relate it to their exiting knowledge. Although highlighting shows some efficacy, as do all of the low effectiveness techniques, a student's time would be better spent using more effective strategies. ${ }^{86}$

Cramming, is another low effectiveness method students typically use to learn. ${ }^{87}$ Students tend to wait until close to an examination to study and study in increasingly longer blocks. Students usually spend increasing amounts of time studying as the test date nears. ${ }^{88}$

81. See discussion infra Part IV.

82. BROWN ET AL., supra note 73, at 3; Improving Students' Learning with Effective Learning Techniques, supra note 77 , at 29.

83. See discussion infra Section IV.A.

84. Joseph Stromberg, Rereading is Inefficient. Here are 8 Tips for Studying Smarter, Vox MEDIA (Jan. 16, 2015), https://www.vox.com/2014/6/24/5824192/study-smarter-learnbetter-8-tips-from-memory-researchers (citing BROWN ET AL., supra note 73). at 21 .

85. Improving Students' Learning with Effective Learning Techniques, supra note 77,

86. BROWN ET AL., supra note 73 , at 3-4.

87. Id. at 3 .

88. Jack Michael, A Behavioral Perspective on College Teaching, 14 BEHAV. ANALYST 229, 233-34 (1991) (this tendency is called the "procrastination scallop"). See discussion infra Section IV.D. 
These are the most common study techniques used by students, and have served them well as undergraduates or they would not likely be in law school. But clearly, law school is different from most undergraduate majors, and retention of some of the learning in early courses may be key to success in later courses-and for certain, most first year courses will be tested soon after graduation in a bar examination.

\section{TECHNIQUES WITH HigheR UTILITY TOWARDS LONG-TERM RETENTION OF LEARNING}

In this section I detail some highly effective learning techniques. Long term retention of material should be the goal of every teacher, student, and administrator. There are many highly effective learning techniques, and I will feature a few here, with some suggestions for helping your students take advantage of them. Remember they are learning techniques, and not teaching techniques, but we can adjust the way we teach to help our students embrace them to learn more effectively. Before discussing the most relevant, I would like to recommend two books that present these techniques in a very approachable narrative - stories that explain and show how they have helped people to become better learners.

The first is "Make It Stick: The Science of Successful Learning," ${ }^{, 89}$ written by a novelist and two scientists. It deftly explains the highly effective learning techniques, in part through stories of individuals and the ways they adopted these methods, sometimes by design, but usually by fortuitous accident. ${ }^{90}$ Equally readable is "How We Learn: The Surprising Truth About When, Where, and Why It Happens." 91 Written by a science journalist, he explains the learning techniques and his own approach to using them. I recommend every student and educator read at least one of these books. For law professors, there is also an excellent law review article by Professor Jennifer Cooper that explains these highly effective learning techniques and her reasoning on why they should be effective in training our law students: "Smarter Law Learning: Using Cognitive Science to Maximize Law Learning., 92

Below are some techniques that may be counter-intuitive to the way we think about learning, yet have been shown in empirical studies to be the most effective ways to effectively learn.

\section{A. Retrieval Practice or Practice Testing}

In the scientific literature, this effect is usually referred to as practice testing, but I use the term retrieval practice with my students for the chilling effect the

89. BROWN ET AL., supra note 73.

90. E.g., id. at 1-2.

91. Benedict Carey, "How We learn: The Surprising Truth about When, WHERE, AND WHY IT HAPPENS (2014). Those of you who attended the AASE ("Association of Academic Support Educators") Conference in Chicago in 2015 may have received a copy courtesy of BARBRI, a commercial bar preparation company.

92. Jennifer Cooper, Smarter Law Learning: Using Cognitive Science to Maximize Law Learning, 44 CAP. U.L. REv. 551 (2016). 
word "testing" has on them. ${ }^{93}$ Not just on students, the word testing has become a loaded term with public debate over the value of standardized testing. ${ }^{94}$ Retrieval practice is hardly new science, as the effect of testing has long been known. When we cause our brain to retrieve a fact, as in when we are being tested on our knowledge, the brain is working harder than when just rereading material. ${ }^{95}$ Studies have shown that the brain re-stores facts in the brain in a different manner than it did in the original learning. ${ }^{96}$ Retrieval practice is superior to rereading materi$\mathrm{al}^{97}$ in part because it disrupts the "illusion of knowledge." 98

The effect of retrieval practice can be easily put into practice in the classroom. Formative assessment is critical to learning-not just so that students can gauge their knowledge before the summative assessment in time to correct their misunderstanding-testing is learning. ${ }^{99}$ As instructors, we can help our students learn with more formative assessment. As formative assessment should be low or no stakes, ${ }^{100}$ these assessments do not even have to be graded or very formal, but graded quizzes and midterms - if low stakes-certainly qualify. You can use multiple choice questions in class as an opportunity for students to assess their own knowledge, and as an opportunity to discuss why each answer was right or wrong. ${ }^{101}$

Students should be encouraged to employ this technique in their own study. One simple way is when reading a text for the first time, to cover up the text that you have just read, perhaps a rule, and see if you can recall, or retrieve that information. The work in retrieving that material is part of what makes the resulting memory more durable. ${ }^{102}$ The process of retrieving that information builds stronger, more durable bonds to the learning. Students can also implement retrieval practice by using paper or electronic flash cards, by working through problems in their texts, or completing practice exams. ${ }^{103}$

93. Improving Students' Learning with Effective Learning Techniques, supra note 77, at 29. I am not the only one who avoids calling it "testing" for similar reasons. CAREY, supra note 91 , at 93 .

94. CAREY, supra note 91 , at 93.

95. Id. at 94.

96. Id. Carey is recounting his conversation with Roediger, one of the authors of "Making It Stick," BROWN ET AL., supra note 73.

97. BROWN ET AL., supra note 73, at 41-44.

98. See discussion supra Section III.D.

99. CAREY, supra note 91, at 93-94.

100. David J. Nicol \& Debra Macfarlane-Dick, Formative Assessment and SelfRegulated Learning: A Model and Seven Principles of Good Feedback Practice, 31 STUD. HIGHER Educ. 199, 212 (2006).

101. For active classroom techniques, see SCHWARTZ ET AL., supra note 23, at 97-135.

102. CAREY, supra note 91 , at 94 .

103. Improving Students' Learning with Effective Learning Techniques, supra note 77, at 29. 
In another book that I highly recommend, "Small Teaching: Everyday Lessons from the Science of Learning" by James M. Lang, ${ }^{104}$ you can find many other simple ways to bring the power of retrieval practice into your classroom, such as opening questions at the beginning of class in which students are asked to recall what they learned in the previous class. ${ }^{105}$ He also advocates low stakes quizzes, and reflection as a method of retrieval practice. ${ }^{106}$

\section{B. Reflection}

Reflection on one's learning has many benefits to the learner. I often treat reflection as its own highly effective learning technique, but it is actually a form of retrieval practice. In the final minute or two of class, instructors can ask students to write down what they thought the most important concepts were in that particular class. They can be assigned a "minute paper," in which they recall certain material, writing it out in the final minute of class. Another option is to have them write down question about certain material, or anything that is still confusing to them. ${ }^{107}$ These papers also provide assessment for you, letting you know how effective you were in helping your students understand the material and directing you in your efforts to clarify confused doctrines. Some faculty members make these quick reflection papers a "ticket out of class."

\section{Pretesting, Priming or Generation}

Pretesting is another variation on the testing effects of retrieval practice. $^{108}$ The effects of testing after studying are clearly beneficial, but surprisingly there is also a benefit to pretesting, testing on material even before the student has begun studying it. The student is likely to perform poorly on a pretest, but when presented with the correct information, this pretesting of unknown material actually results in long term retention of the material. ${ }^{109}$ As Benedict Carey relates, "guessing wrongly increases a person's likelihood of nailing that question, or a related one, on a later test." $" 110$

With the level of preparation we expect of our students, pretesting directly in the classroom can be difficult. Still, we can help our students to take advantage of this effect. Many undergraduate texts begin each chapter with questions about the material the student is about to read, and there are some legal texts available that do this as well. We can select texts that include pretests, or alternatively, we can include some pretesting questions in our syllabi. Although students do not

104. James M. Lang, SMall Teaching: EVeryday Lessons from the SCIENCE of LEARNING (2016).

105. Id. at 39 .

106. $I d$.

107. Id. Although Lang did not invent these, he does a great job of explaining them.

108. CAREY, supra note 91 , at 95.

109. Lindsey E. Richard, Nate Kornell \& Liche Sean Kao, The Pretesting Effect: Do Unsuccessful Retrieval Attempts Enhance Learning?, 15 J. EXPERIMENTAL PSYCHOL. 243, 254 (2009).

110. CAREY, supra note 91 , at 95 . 
usually consult their syllabus regularly, we can make our syllabi documents an active part of each course. ${ }^{111}$ Lang recommends that students be required to bring their syllabus to each class, and uses his syllabus to encourage students to recall earlier learning. ${ }^{112}$ Students can also be told of the power of this pretesting effect and can generate their own pretest questions and answers when studying alone or in their study groups.

Pretesting usually results in students getting many of the answers wrong, so the experience may not be initially pleasant, especially to those students with a pessimistic attribution style. ${ }^{113}$ Students should be reminded that the classroom and their study periods are places for exploration and challenges, and that making mistakes made in pushing the limits of their knowledge is a powerful means of learning information for the long term.

\section{Distributed Practice, Spaced Practice, or Spacing}

Perhaps the least intuitive of all the highly effective learning techniques, spacing is also among the most powerful in terms of long-term retention of material. ${ }^{114}$ Spaced practice is actually concerned with the scheduling of learning episodes, not the method that the student uses to study. ${ }^{115}$ This method is superior to the typical scheduling method that students use for studying, otherwise known as "cramming" or mass studying. Using the same amount of study time over a series of learning sessions leads to greater long-term retention of material. Unfortunately, spacing your study appropriately does not usually "feel" like it is working, particularly for people who have a history of cramming for tests. ${ }^{116}$ Add to this fact that in terms of results on a single test, cramming works as well or slightly better for that one test. ${ }^{117}$ The difference is with spaced practice, much more of the material will be retained, which should be the point of learning. This fact should also be of great interest to law students, who will be seeing many of the subjects they study for the bar exam up to two and a half years later from their original learning of the material.

Early studies showed the unexpected results of various spacing regimens. One study reviewed spacing study with one day between study sessions, thirty days between sessions, and cramming near the test. ${ }^{118}$ The students studied the same amounts of time up until the test date. For the first test, the one-day interval

111. See discussion infra Section IV.D.

112. LANG, supra note 104 , at 36.

113. See discussion supra Section III.A.3.

114. CAREY, supra note 91 , at 76 ("The truth is, nothing in learning science comes close [to spacing] in terms of immediate, significant, and reliable improvements to learning."); Improving Students' Learning with Effective Learning Techniques, supra note 77, at 35-40.

115. Improving Students' Learning with Effective Learning Techniques, supra note 77, at 36 .

116. BROWN ET AL., supra note 73, at 47.

117. Improving Students' Learning with Effective Learning Techniques, supra note 77, at 38 .

118. Id. at 36 (citing Harry P. Bahrick, Maintenance of Knowledge: Questions About Memory We Forgot to Ask, 108 J. EXPERIMENTAL PSYCHOL. 296, 299-304 (1979)). 
students and the crammers did comparatively well, with their study mostly all within the week before the exam. For students who had their sessions spaced very far apart-the thirty-day interval, the results were poorer than the other two groups. However, when retested on the same material thirty days after the test date with no further study, the thirty-day interval students performed best, followed by the one-day interval students, with cramming students performing the worst. ${ }^{119}$

It follows that the timing of the intervals is important, but more space is not necessarily better. The optimal spacing is not necessarily one day or thirty, instead the optimal spacing of study sessions is based upon the date on which you will need to recall the information-for example, a test date. ${ }^{120}$ For instance, "[i]f the test is in a week, the best interval is a day or two (twenty to forty percent). If it's in six months, the best interval is three to five weeks (ten to twenty percent)." ${ }^{121}$ Another idea is to use a chart, ${ }^{122}$ like this one:

\begin{tabular}{|l|l|}
\hline \multicolumn{1}{|c|}{ Time to Test } & \multicolumn{1}{c|}{ Interval } \\
\hline One Week & One-Two Days \\
\hline One Month & One Week \\
\hline Three Months & Two Weeks \\
\hline Six Months & Three Weeks \\
\hline One Year & One Month \\
\hline
\end{tabular}

In other words, "if you want to know the optimal distribution of your study time, you need to decide how long you wish to remember something." 123 This effect is not just profound in academic settings. Distributed practice also works well for music memorization and for acquisition of skills such as ball tossing, gymnastics, ${ }^{124}$ and acquiring or sharpening hockey skills. ${ }^{125}$

There are many theories as to why this spacing effect works, including the idea that students studying material again too soon may result in them not having to work very hard, which is the key to successful learning, ${ }^{126}$ or perhaps they fall victim to the "illusion of knowledge." 127 Another theory concerns reminding. Similar to practice testing, ${ }^{128}$ reminding a student of prior learning aids in the act

119. Id.

120. Id. at 37.

121. CAREY, supra note 91 , at 78.

122. Id. at 77 .

123. Nicholas J. Cepeda, Edward Vul, Doug Rohrer, John T. Wixted \& Harold Pashler, Spacing Effects in Learning: A Temporal Ridgeline of Optimal Retention, 19 PSYCHOL. SCI. 1095, 1101 (2008).

124. Improving Students' Learning with Effective Learning Techniques, supra note 77, at 37 .

125. BRowN ET AL., supra note 75, at 65-66.

126. Improving Students' Learning with Effective Learning Techniques, supra note 77, at 36 .

127. See discussion supra Section III.D.

128. See discussion supra Section IV.A. 
of retrieving the former knowledge, creating a new memory of the learning. ${ }^{129}$ Spaced practice also gives the student time to take advantage of the consolidating role of sleep. ${ }^{130}$

In my own classroom, I plan my syllabus to build in review of blocks of material at the appropriate intervals, so that the students can take advantage of the distributed practice effect - even if they end up doing it by rereading. For example, in my first-year torts class last year, I knew my final was on December ninth. I finished my section on intentional torts on September fourteenth, and gave a onehour test (worth ten percent of their grade-low stakes, so formative assessment). With the final exam about three months away, I looked up that interval on the chart above and found the optimal spacing was about two weeks, so two weeks later I gave a quiz. I can repeat the process with discussion or some other assessment on intentional torts periodically. You can build mini reviews of blocks of material all through the semester, and not unduly burden your schedule as you relate and distinguish the earlier learned concepts with and from the new material you are teaching.

Students can make good use of this effect in planning their study schedules to avoid cramming and the panic that accompanies that technique. Students naturally spend increasing amounts of time studying as the time for the examination nears, a practice termed "procrastination scallop" by scientists studying this effect. ${ }^{131}$ Again, the spaced practice method is so counter-intuitive that it requires a great leap of faith for students to adopt and eschew the methods that have brought them academic success this far in their careers. I have been attempting to get students to employ this technique with marginal success in my role as the Dean of Academic Support at my school. Although I present this material during our orientation the week before law school and have it reinforced regularly by our academic support TAs at their weekly meetings, I find that very few students are willing to adopt this technique, save for some cognitive science or education majors, and perhaps a few of the TAs themselves. Each year, I make new converts, but the process has been slow.

On a larger scale, our school is attempting to harness the power of distributed practice in our miniature Multistate Bar Examination ("MBE") ${ }^{132}$ program. Many schools have regular "mini" MBEs, so this is nothing new. What we have instituted for all students who have entered fall 2015 and later, is a mandatory test at the end of each semester comprised of MBE style questions of the MBE tested subjects they have taken. We distribute simple outlines for classes they are not

129. Improving Students' Learning with Effective Learning Techniques, supra note 77 , at 36.

130. CAREY, supra note 91, at 195. Sleep is not exactly a learning method, but "that unconscious downtime clarifies memory and sharpens skills - that it's a necessary step that locks in both. In a fundamental sense, that is, sleep is learning." Id. at 211.

131. Michael, supra note 88 , at 233-34.

132. The MBE is a six-hour, 200-question multiple-choice examination developed by the National Conference of Bar Examiners ("NCBE") and is administered in almost every U.S. state. Multistate Bar Examination, NAT'L CONFERENCE OF BAR EXAMINERS (last visited Nov. 1, 2017), http://www.ncbex.org/exams/mbe/. 
currently taking and encourage the students to review the material before the test. Originally the idea was to gather data on student retention of material annually, but we are attempting to take advantage of the spacing effect in reviewing the material with these long gaps. Our plan is that the students will retain more of the material that they learn in the first three semesters of law school so that they have less material to relearn when they study for the bar exam. Naturally, many of our students resent any additional demands made of them, and complain bitterly about this extra work. More students than I would care to enumerate have also sat down for the test, picked random answers and left within ten minutes or less. We are now requiring a good faith effort on the tests and appealing to their honor as an Aggie. ${ }^{133}$ In the future, we would like to require a passing grade in the hope that students will take these tests more seriously, but the faculty seems unwilling to take make this a graded graduation requirement. ${ }^{134}$

\section{E. Interleaved Practice or Interleaving}

Law students-actually all students-must learn many different subjects, and an intuitive and common approach is to study each topic in discrete blocks of time until mastery. Studies have shown that interleaving subjects or approaches to learning leads to more effective long-term learning. ${ }^{135}$ Instead of studying one topic until mastery, interleaving topics leads to better retention of the material. The interleaving effect is closely related to the spacing effect, and seems as counterintuitive to most students. In a well-known interleaving experiment by two scientists, Robert Bjork and Nate Kornell, they not only tested the effect of interleaving, but also asked the participants which method of study, block or mixed, helped them learn better. ${ }^{136}$ Even after the final exam, they rated block study as better or equal to mixed study. Even when shown they had done better with interleaving, many of the students still did not believe interleaving helped them learn better. ${ }^{137}$

133. At Texas A\&M, even suggesting that someone might not be living up to the six core Aggie values elicits a visceral response. An "Aggie" refers to students, graduates, and sports teams at Texas A\&M.

134. I know of schools that require passing a mini MBE as a requirement in their second or third year. Students at unaccredited California schools must also pass a mini MBE, but the purpose for that is somewhat different from ours. One school permits multiple attempts, but the student must pay the cost of each additional test after the first one, which are purchased from a commercial bar review company.

135. Improving Students' Learning with Effective Learning Techniques, supra note 77, at 43-44 (citing Kristin H. Mayfield \& Philip N. Chase, The Effects of Cumulative Practice on Mathematics Problem Solving, 35 J. Applied Behav. Analysis 105, 105 (2002)). The other learning techniques featured here, i.e., retrieval testing, reflection, pretesting, and spacing, were rated as having high utility for effective learning. The authors of this study found interleaving to have moderate utility. $I d$. at 44 . The authors note a relative scarcity of study of interleaving. Id.

136. CAREY, supra note 91, at 164 (citing Nate Kornell \& Robert A. Bjork, Learning Concepts and Categories: Is Spacing the "Enemy of Induction"?, 19 PSYCHOL. SCI. 585, $585(2008))$.

137. Id. (citing Kornell \& Bjork, supra note 136, at 588). 
Helping students to change their usual study behavior is difficult, as most of us are not very good at self-assessment.

With interleaving, you switch subjects before you finish the first. This process works equally well with skills. The Los Angeles Kings of the National Hockey League formerly drilled on one skill at a time, until they were convinced of the value of interleaving, and instead now players move from one practice drill station to the next, each with a different maneuver to take advantage of this powerful learning technique. ${ }^{138}$

In the classroom, teachers can work with different subtopics, taking advantage of this effect while also incorporating spaced practice. As Lang suggests, open or close your class with review of prior material. ${ }^{139}$ Students on their own can mix up their study of the various courses they take-if you can convince them to take advantage of this powerful technique.

\section{F. Other Methods of Moderate Utility in Effective Long-Term Learning Retention}

The following two have been rated as having moderate utility in the retention of learning, but are not likely to be used in the classroom. Thus, I consider them beyond the scope of this article, but provide a brief summary.

\section{Elaborative Interrogation}

Elaborative interrogation involves turning facts to be learned into "why" types of questions and then answering them. ${ }^{140}$ This technique works well when the information to be learned has familiar concepts. Elaborative interrogation may be useful to law students as it is appropriate when you need to understand information as well as remembering it. It may not always be an appropriate method for learning new material, as a student must have sufficient related knowledge to use this technique successfully. ${ }^{141}$

\section{Self-Explanation}

Self-explanation is similar, but distinct from elaborative interrogation in that they both use the "why" types of questions. ${ }^{142}$ In this technique a student generates their own explanation of presented instruction to integrate the new knowledge with their prior learning, and fills in gaps by making tacit inferences. ${ }^{143}$ I often suggest this method to students who choose not to join study groups. They

138. BROWN ET AL., supra note 73, at 65-66.

139. LANG, supra note 104 , at 39.

140. Improving Students' Learning with Effective Learning Techniques, supra note 77, at 8 .

141. Id. at 9 .

142. Id at 8 .

143. Id. at 11-12. 
can get similar benefits to teaching their peer, by explaining the material aloud to themselves. $^{144}$

\section{CONCLUSION}

After examining constructive alignment's assessment of our students, and the important role that classroom and program assessment plays in helping our students achieve success, it is clear that appropriate and quality assessment is critical. Although law students may not agree, three years is a short time to master the skills and learn the law required of them to become practicing lawyers. When planning our classes based upon our desired outcomes and the methods that we will use to determine if they have been met, we need to implement strategies to help our students become self-regulated learners, but also to work efficiently. Fostering student adoption of the highly effective learning techniques may be easier if we model their use in our classes, so that students might see their effect.

It is important to be transparent in your efforts in using the techniques with the students so that they do not, perhaps unwittingly, corrupt your process. As an example of this, most bar review companies have been employing some of these methods in their courses. One strategy they are employing is to have formative assessment questions every fifteen to twenty minutes or so during a lecture period. While watching the video lecture at home, some students report skipping the questions until later, when they will have had a chance to study the material, as they were not confident of their knowledge when the questions appear. They bypass the built-in opportunity for retrieval practice and forego the chance to take advantage of making mistakes when they do not only not count, but may be a superior method of learning the material for the long-term. These superior methods cannot be introduced once to students, they must be reinforced and modelled regularly for students to embrace them.

144. You can also explain the concepts you are learning to your dog, who will likely be happy to have you chatting with him or her. 